розвитку дитини. Альтернативною формою здобуття знань, соціального досвіду, життєвої компетенції дітьми з особливими потребами є інклюзивна освіта. Підготовку цих дітей до навчання в загальноосвітніх школах потрібно здійснювати заздалегідь - у дошкільних закладах, які потребують реорганізації, зокрема, зарахування до педагогічно-виховного складу логопедів та асистентів вихователів. Важливим напрямом цієї підготовки є робота 3 формування картини світу у свідомості неповнолітніх i усунення порушень у застосуванні мовних засобів - репрезентантів цієї картини.

\title{
Література
}

1. Використання невербальних засобів комунікації у корекційній роботі з дітьми старшого дошкільного віку із ЗПР. - [Електронний ресурс]. - Режим доступу: http://www.logopediya.com.ua/the-news/284-2012-02-19-20-23-17. 2. Гавриш Н. Відбиття в мовленні дошкільників особливостей світорозуміння. - [Електронний ресурс]. - Режим доступу: http://ukrdeti.com/2010/2_a4_2010.html 3. Гавриш Н. Розвиток мовленнєво-творчої діяльності в дошкільному дитинстві : [монографія] / Н. Гавриш. - Донецьк : Лебідь, 2001. - 238 с. 4. Горєлова А. Формуємо зв'язне мовлення / А. Горєлова // Дошкільне виховання. - 2004. - № 4. - С.15-17. 5. Інформація відділу інклюзивного навчання та інтернатних закладів про запровадження інклюзивного навчання - [Електронний ресурс]. - Режим доступу : http://mon.gov.ua/index.php/ua/diyalnist/osvita/doshkilna-ta-zagalna-serednya/osvita-osib-z-osoblivimi-

potrebami 6. Когут М. В. Принципи розвитку мовлення та навчання дітей дошкільного віку рідної мови / М. В. Когут // Мовленнєва веселка. - 2006. - № 1-2. - С.1-5. 7. Майбутній вчительвихователь: пріоритети гуманістичної парадигми. - [Електронний ресурс]. - Режим доступу: http:// izmix.org.ua/stat.php?id=11 8. Особливості пізнавальної діяльності дітей із затримкою психічного розвитку. - [Електронний ресурс]. - Режим доступу: http://ua-referat.com 9. Пахомова Н. Мовленнєва готовність дітей дошкільного віку з тяжкими вадами мовлення / Н. Пахомова // Дефектологія. - 2005. - № 3. - С. 48-50. 10. Перші кроки до інклюзивного навчання. - [Електронний ресурс]. - Режим доступу: Ошибка! Недопустимый объект гиперссылки. the-news/101-2011-0515-18-55-26. 11. Пироженко Т. А. Мовленнєве зростання дошкільника / Т. А. Пироженко // Науковометодичний посібник. - К. : Грайлик, 1999. - 40 с. 12. Пироженко Т. А. Мовленнєвий розвиток дитини дошкільного віку / Т. А. Пироженко // Актуальні проблеми сучасної української психології: Наукові записки Інституту психології ім. Г.С. Костюка АПН України / за ред. академіка С. Д. Максименка. - К. : Нора-Друк, 2003. - Вип.23. - С.281-293. 13. Шкльода В. М. Розвиваємо мовлення дошкільників / В. М. Шкльода // Мовленнєва веселка. - 2003. - № 17-18. - С.1-12.

УДК 378.147:78+372 (07)

\author{
О. А. Бєлікова, \\ асистент, \\ Криворізький педагогічний інститут \\ ДВНЗ «Криворізький начіональний університет»
}

\section{ПІДГОТОВКА ВИХОВАТЕЛІВ ДО РОЗВИТКУ ОСОБИСТОСТІ ДОШКІЛЬНИКА ЗАСОБАМИ МУЗИЧНОГО МИСТЕЦТВА}

Бєлікова О. А. Підготовка вихователів до розвитку особистості дошкільника засобами музичного мистецтва.

У статті висвітлено змістовий компонент професійної підготовки майбутніх фахівців дошкільної освіти з урахуванням його модернізації. Звертаючись до музичного мистецтва через популяризацію серед вихователів методів та прийомів музикотерапії, приклади яких надаються в статті, окреслено їх вплив на розвиток особистості дошкільника.

Ключові слова: професійна підготовка вихователя, музичне мистецтво, музикотерапія.

Беликова О.А. Подготовка воспитателей к развитию личности дошкольника средствами музыкального исскуства.

В статье раскрыт содержательный компонент профессиональной подготовки будущих специалистов дошкольного образования с учетом его модернизации. Обращаясь к музыкальному искусству посредством популяризации среди воспитателей методов и приёмов музыкотерапии, 
примеры которых приводятся в статье, обозначено их воздействие на развитие личности дошкольника.

Ключевые слова: профессиональная подготовка воспитателя, музыкальное искусство, музыкальная терапия.

Belikova O. A. Training of educators for personal development of preschooler by means of music arts.

An author exposes the profound component of professional training of future specialists preschool education, taking into account it's modernization. Speaking to the musical art by means of popularization among the educators of methods and receptions of music therapies, the examples of which are given in the article, an author outlines their influence on development of personality of preschool child.

Key words: professional training of educator, musical art, musical therapy.

Професійна підготовка майбутнього вихователя, що визначається державним стандартом освітньо-кваліфікаційної характеристики (ОКХ) за спеціальністю 6.010100 «Дошкільна освіта» напряму підготовки 0101 «Педагогічна освіта», свідчить про розширення професійних компетенцій вихователя, що зумовлюється орієнтацією на нові тенденції розвитку освіти в Україні та пріоритети сучасності. Сьогоднішній педагог дошкільної освіти має бути динамічним і мобільним у змінних умовах розвитку українського суспільства й ефективно реалізувати особистісний потенціал, творчо підходити до своєї професійної діяльності. Зокрема, йдеться про набуття музичнопедагогічних знань, умінь, навичок, які сприяють розвязанню творчих завдань навчальновиховного процесу.

Саме оновлення змісту професійної підготовки майбутнього фахівця та орієнтація на формування гармонійної особистості дитини дошкільника зумовило вибір теми нашої статті.

Сучасними підходами до проблеми професійної підготовки кадрів для системи дошкільної освіти опікуються Л. Артемова, Л. Загородня, І. Луценко, М. Машовець, Т. Поніманська, С. Попиченко та інші. Професійну підготовку педагогічних кадрів на засадах компетентнісно-орієнтованого підходу досліджують В. Анищенко, I. Бех, С. Гончаренко, І. Зязюн, А. Залізняк, Л. Кондрашова, О. Михайличенко, О. Сухомлинська. Сучасний погляд на проблему музично-педагогічної підготовки педагогів системи дошкільної освіти розкриває С. Нечай, намагаючись переосмислити мету, зміст і завдання музично-педагогічної підготовки майбутніх вихователів.

Аналіз сучасної наукової літератури й теоретико-експериментальних праць свідчить, що нині накопичено чималий досвід підготовки вихователя, проте залишається актуальною проблема професійної компетентності майбутнього вихователя ДНЗ (дошкільного навчального закладу), зокрема, особливої уваги набуває модернізація музично-педагогічної підготовки майбутніх вихователів-педагогів.

Mета статmi полягає у висвітленні змістового компоненту професійної підготовки майбутніх фахівців дошкільної освіти. Відповідно до стандарту освіти та задля підвищення музичної культури майбутніх вихователів у статті розглянемо музикотерапію як метод розвитку особистості дошкільника, замислимось над питаннями: чи здатна музика зцілювати?; чи може музика завдавати шкоди?; чи існує «погана» музика? Спробуємо осягнути вплив музики на особистість, чи сприяє музика віднайденню рівноваги, цілісності та гармонії буття, гармонізації психічного життя і всебічного розвитку особистості дитини.

Відповідно до вимог галузевого стандарту вищої освіти за спеціальністю 6.010100 «Дошкільна освіта» напряму підготовки 0101 «Педагогічна освіта», музично-педагогічна підготовка студентів передбачає вивчення нормативної дисципліни «Методика музичного виховання», яка входить до циклу «Професійна та практична підготовка». У межах програми підготовки майбутніх вихователів вивчається тема «Музична терапія та її вплив на розвиток та виховання особистості дошкільника», яка набуває особливої актуальності й доцільності застосування у практичній діяльності вихователя ДНЗ. 
Особливе місце музики в сучасному житті людини потребує усвідомленого ставлення до себе. Використовуючи досягнення науки й техніки (сучасні засоби звукозапису та звуковідтворення), музика розширює коло свого впливу в сучасному просторі буття особистості, вона перетворюється на «музично-звучащий простір» (В. Саранін). Дійсно, сучасна людина практично не може бути відділеною від звучання та перебуває в постійній залежності від музичних смаків, потреб та настроїв навколишнього світу. Безперервна зануреність у музику робить їі супутнім компонентом сучасної особистості. Стає очевидним, що музика $\epsilon$ невід’ємною частиною системи людських координат, які перетворює в енергійно-інформаційні складники сучасності. Проникаючи практично в усі сфери людської життєдіяльності, вона дозволяє говорити про виключну значущість як потужного духовного та біологічного стрижня, на якому будується людське життя. Наголосимо, що науковці починають обговорювати питання, пов'язані зі співвіднесенням «мелодичного повітря» із низкою екологічних вимог, високими параметрами культури його формування та використання.

В осмисленні цінності музики як феномену спостерігаємо спрямування наукової думки від розуміння іiі як «абсолютної музики» (К. Дальхауз, В. Вакенродер, Л. Тик, Е. Т. А. Гофман, Р. Вагнер, Л. Фейербах, Ф. Ніцше), «рухомі форми, що звучать» (Е. Ганслік), «естетичного споглядання як благоговіння» в епоху романтизму, мистецтва, що пробуджує в людиниас благородні почуття (Х. Кох), «мистецтво, що підіймається до моральних почуттів, завдяки яким людина набуває моральну цінність» (І. Зульцер), «звуко-мова» (Й. Маттезон), мистецтво думки і змісту (А. Михайлов), «мистецтво інтованого змісту» Б. Асаф'єв, художнього відображення дійсності у звучанні [3], як одного із способів символічного мислення [8, с. 334], до визначення їі як складного поліморфного, поліфункційного енергійного утворення, сутність і вплив якого залежить від багатьох компонентів, що трансформує її в особливу форму культури, яка має власний смисл, певний ряд образів, механізмів упливу на людину та суспільство [6, с. 3].

Один із найбільш стійких семантичних зв'язків поняття «музика» виявляється в синонімічності й навіть тотожності його з поняттями «радість» $\mathrm{i}$ «свято» (акадське слово «negütu»- музика - походить від «negu»-радість).

На основі вчення Б. Асаф’єва в курсі «Музика як вид мистецтва», В. Холопова пропонує своє розуміння музики як виду мистецтва, заснованого на системі звукоінтонацій, що історично склалася через емоційну дію, що втілює які-небудь ідеї, образи відчуттів і станів людини, можливо - предметів і подій дійсності, що реалізовується в конкретних творах, побудованих за певними принципами композиції й підносяться слухачу музикантом-виконавцем [7].

Музика тісно пов'язана зі здоров'ям людини, підтримуючи, зміцнюючи або руйнуючи його оптимальний стан. Багаточисленні дослідження підтверджують, що «людина $\epsilon$ звучащим мікрокосмом, i кожний із напрямів музики виконує в його настроюванні на включення в форми життєдіяльності, певну роль» [6, с. 3-4]. Така ситуація зумовлює осмислення музики як біологічної й антропологічної константи, що перетворює іiі на смислоутворювальний елемент екологічності буття людини.

Численні наукові розвідки, що вивчають музику, розглядають ії під різним кутом зору. Цікавими й актуальними, з позиції практичного застосування в роботі вихователя ДНЗ, $є$ накопичені знання про закономірності терапевтичного впливу музики, що були узагальнені й оформлені в галузь психологічної науки - музикотерапію, яка становить напрям відновлюваної медицини, в методологічній основі якого лежить використання музичного мистецтва з лікувально-профілактичною метою.

Сучасна наукова думка в галузі музикотерапії розвивається в кількох напрямках. Так, вивчення художньо-естетичних закономірностей музичного сприйняття здійснюється в естетичних та музично-теоретичних роботах І. Догеля, А. Костюка. Психофізіологічні аспекти дослідження музикотерапії належать В. Бехтереву, І. Павлову, І. Сеченову, В. Полякову, Б. Любан-Плацца, О. Белову, І. Тарханову та інших. 3 другої половини 
XX ст. музикотерапія вивчається й використовується 3 лікувальною метою в різних напрямках медицини й у психології, зокрема, спеціальній. Найбільш розробленим аспектом у музичній психології $\epsilon$ психологія музичного сприйняття, дослідженням якої займалися музикознавці та теоретики Ю. Тюлін, Б. Асаф’єв, Б. Яворський, Л. Мазель, М. Блінова, Ю. Алієв та інші. Сучасні вітчизняні дослідження музикотерапії представлені працями Г. Побережної, У. Дудчак, Л. Ігнатьєва, І. Крутій та інші.

Основою музично-терапевтичного впливу $є$ феномен резонансу, що «становить різке зростання амплітуди коливань у будь-якій системі під впливом зовнішніх сил. При цьому частота власних коливань системи збігається із зовнішньою частотою. Одночастотні коливання об'єднуються й не просто додаються, а відбувається потужне нарощування якості, значний енергетичний стрибок» [5, с. 24]. У фізичному аспекті проявом резонансу $\epsilon$ вібрація. Підтвердженням цієї думки є дослідження доктора Г. Шоу [1], який пояснює вплив музики на здоров'я людини дією вібрації звуків. Звуки створюють енергетичні поля, що провокують резонувати клітини організму. Людина сприймає музику, а вона, у свою чергу, нормалізує ритм дихання, пульс, тиск, температуру, знімає м'язову напругу. Тому правильно дібрана мелодія має сприятливу дію, допомагає зняти емоційну напругу, урівноважує настрій, сприяє підвищенню емоційного тонусу.

Сфера впливу музики багатогранна й охоплює фізіологічну, соматичну та психологопедагогічну сторони. Такий різнобічний уплив музики на психіку людини зумовив розуміння музикотерапії як одного із перспективних сучасних методів гармонізації психофізичного стану особистості. Вона $€$ відображенням i вираженням суспільноісторичної сутності людини, невід'ємною частиною її суспільної свідомості, чинником розвитку. При цьому, музикотерапія посідає своє унікальне місце, створюючи позитивний уплив як на дитину, так і на дорослого тим, що стосується емоційно-вольової (фізичної та душевної) й розумової сфер.

Г. Побережна виокремлює такі рівні музично-терапевтичного впливу: фізіологічний, психічний, сакральний. Музично-терапевтичний уплив на фізіологічному рівні можна описати такою послідовністю взаємодії: звук - вухо - барабанна перетинка - голосовий апарат - гіпоталамус - підкірка - кора головного мозку - нервова система. Психічний рівень продукується разом із настроєм музики. Це особливий душевний стан, що поєднується зі здатністю проникнути в найглибший шар змістовності музичного вислову. Сакральний - ми розуміємо як рівень глибокого філософського узагальнення та пов'язуємо із катарсисом, очищенням людської душі через страждання, емоційні переживання.Кожний музичний твір сповнений певними засобами музичної виразності (ритм, темп, мелодія, гармонія, музична форма, жанр, динаміка, тембр тощо), що є відображенням певного стану людської духовності. Безумовно, духовність $є$ переживанням і взаємодією людини з буттям. У межах нашого дослідження під одним із аспектів «буття» потрібно розуміти музичний твір, у якому в унікальній узагальненій формі, завдяки таланту композитора, передається комплекс емоційних ставлень як таких. Людина за своє осмислене життя не завжди відчуває такі емоційні переживання, якими може бути сповнене людське життя та яким збагачує іiі мистецтво. Високохудожній музичний твір надає їй змогу відчути розмаїття емоційних станів, пережити цікаві життєвих психологічні ситуації, тобто - 3 «іншим», пережити в співбутті, наповнити свій духовний світ завдяки новим відчуттям. Підтвердженням цього є думка Ю. Білодіда [2, c. 105] про те, що духовна особистість пізнає «іншого» на основі цілісного сприйняття іншодуховного здебільшого інтуїтивними засобами у процесі співпереживання буття. Переживання становить найсокровенніше, найінтимніше та невід'ємне від індивідуальної форми суб'єктивного. Переживання, що відбувається під час естетичної ситуації, базуються на безкорисливому інтересі суб'єкта до об'єкта, тобто ставленні духовного, а не біофізичного рівня. Виховна сила мистецтва базується на тому, що спонукає людей до «переживання себе», оскільки «пережити» щось означає долучити певне явище, подію, дійство до свого власного життя. У практичній життєдіяльності людини сила впливу тих 
чи тих подій, вражень визначається тим, якою мірою вони викликали переживання, тобто наскільки вони заглибились у емоційну сферу психіки. У випадку, коли переживання не відбулось, а почуте, побачене лишилось саме почутим і побаченим, а не сприйнятим, засвоєним, осмисленим, - воно не відбивається на духовному рівні, характері, світосприйнятті особистості. А у випадку, коли певне явище, подія пережиті людиною, залучені в структуру свідомості, то це трансформує емоційне, глибинно-особистісне ставлення до життя, цінності та переконання людини. Тоді мистецтво стає здатним будувати і трансформувати свідомість особистості у пї цілісності - єдності поглядів, світогляду, світосприйняття, переконань і характеру, тому що воно слугує не лише засобом спілкування і просвітництва, а й способом розширення життєвого простору, досвіду особистості і здобуття нових цінностей. Розширюючи рамки особистісного життєвого простору, мистецтво трансформує «чужий» досвід, роблячи його «своїм» через досвід власного переживання.

Водночас, в аспекті музичної терапії виховні можливості музики не пов'язані з іiі естетичною цінністю. $€$ «погана», 3 точки зору музичного мистецтва, але нешкідлива музика. А $\epsilon$ музика шкідлива, 3 психологічної позиції, хоча написана відомими композиторами. Музика, яку можна назвати шкідливою, відрізняється частим дисонансом, відсутністю форми, нерегулярністю ритмів. Наприклад, рок-музика впливає ультра- i інфразвуками, які ми не відчуваємо, але «чують» усі наші органи, вона здатна руйнувати мозок за принципом «25-го кадру». Деякі музикознавці вважають, що й класична музика може шкідливо впливати на психологічний стан слухачів, оскільки є музика, що «заражає» апатичністю, слабкістю, стражданням. Отже, ефективність музичнотерапевтиного впливу визначає дотримання певних принципів, поміж яких виокремлюють: 1) не нашкодь (відповідність використання стилю музики поставленій музично-терапевтичній меті); 2) індивідуальний підхід (рецепти музичної фармакології; відповідність музичного репертуару аудиторії слухачів, наприклад, «Похорон ляльки» із «Дитячого альбому» П. Чайковського не рекомендується демонструвати дітям тощо); 3) принцип вільного музикування; 4) принцип систематичного оцінювання результатів і погляду медицини.

На думку В. Петрушина, основну роль у моделюванні емоції відіграють лад і темп, інші компоненти, такі як мелодія, ритм, динаміка, гармонія, тембр - залишаються допоміжними, хоча це може здаватись незвичним. Розгортаючи думку, автор зауважує, що від творів музикантів «старих» майстрів до творів сучасності збільшується структурна й семантична складність музичної тканини, при цьому самі емоції суттєво не змінюються $[4$, c. 22].

Наукові знання з біології та медицини свідчать про те, що сильну дію на організм людини здійснює ритм. Ритми музичних творів перебувають у діапазоні від 0,6 до 1,5 Гц це частота, близька частоті серцебиття й дихання. Життя людського організму засноване на різних ритмах - дихання, серцебиття, різних діях. Організму людини властиво адаптуватися до зовнішніх дій, тому під час прослухування музики робота серця й дихання копіює ритм музичного твору.

У результаті численних психолого-педагогічних та соціологічних досліджень установлено, що під впливом музики, яка відповідає функціональному станові організму, такі психічні процеси, як пам’ять покращуються на 45-50 \%, а увага - на 25-30 \%. Музика активізує розумові здібності особистості, а також працездатність і зосередженість, здатна розвивати й підвищувати інтелект людини. Звукові вібрації стимулюють кровообіг, емоційний тонус. Ці дослідження підтверджують фізіологічну гіпотезу музикотерапії: поєднання ритму музики з біоритмікою людини.

На думку Г. Побережної [5], задля того, щоб музика надійно ввійшла в повсякденне життя людини, доцільно створити «музичну аптеку». Ії склад становлять: 1) твори «золотого фонду» музичної класики («Либідь» К. Сен-Санса; «Адажіо» й «Танок маленьких лебедів» із балета «Лебедине озеро» П. Чайковського; його ж вальси із 
«Лускунчика» та «Сплячої красуні»; «Аве Марія» Й.Баха, Ф. Шуберта тощо); 2) класичні твори, написані спеціально для дітей: «дитячі альбоми» П. Чайковського, Р. Шумана, М. Равеля, К. Дебюсі, українських композиторів: В. Косенка, М. Степаненка, Г. Соська, О. Нежигая та інших; 3) фольклорні мотиви (колискові у виконанні Н. Матвієнко, М. Пилипчак), оскільки генна пам'ять потребує свого вияву, тому українські веснянки, колядки, щедрівки, потішки будуть досить корисними у практичному застосуванні; 4) сучасні дитячі пісні, в тому числі з відомих мультфільмів; 5) фонова інструментальна музика (допомагає сконцентруватися над виконанням творчих завдань, наприклад, під час малювання, ліплення, конструювання тощо).

Досвід роботи з майбутніми вихователями ДНЗ під час виробничої практики виявив доцільність використання такого інструментального музичного репертуару (табл. 1), що зорієнтує вихователя у світі класичної музики, написаної спеціально для дітей, залучаючи кращі світові зразки музичних творів вітчизняних та зарубіжних композиторів.

\section{Музика для дітей}

Таблиия 1

\begin{tabular}{|c|c|}
\hline $\begin{array}{l}\text { П. Чайковський. «Дитячий } \\
\text { «Пори року». }\end{array}$ & $\begin{array}{l}\text { В.-А. Моиарт. Маленька нічна серенада. } \\
\text { Л. Бетховен. Симфонія № } 6 \text { «Пасторальна» } \\
\text { (фрагменти). А. Вівальді. «Пори року». }\end{array}$ \\
\hline В. Косенко. «24 Дитячі п’єси» Оп.15. & Б. Бритен. «Путівник по оркестру». \\
\hline М. Степаненко. «Дитячий альбом». & Е. Григ. Сюїта «Пер Гюнт». \\
\hline С. Майкапар. «Бірюльки». & К. Дебюсі. «Дитячий куток». \\
\hline $\begin{array}{l}\text { М. Лисенко. Дитяча опера «Коза-дереза» } \\
\text { («Я лисичка, я сестричка»). }\end{array}$ & $\begin{array}{l}\text { Ж. Бізе. «Дитячі ігри». } \\
\text { М. Равель. «Моя матушка-гусиня». }\end{array}$ \\
\hline М. Мусоргський. «Картинки з виставки» . & К. Сен-Санс. «Карнавал тварин». \\
\hline $\begin{array}{l}\text { C. Прокоф’єв. Симфонічна казка «Петя } \\
\text { та Вовк». }\end{array}$ & $\begin{array}{l}\text { П. Хіндеміт. «Ми будуємо місто». } \\
\text { Б. Барток. «Маленькому словаку». }\end{array}$ \\
\hline $\begin{array}{l}\text { Д. Шостакович. Балетна сюїта № 1, №2, } \\
\text { №3, «Танці ляльок», «Шарманка». }\end{array}$ & Р. Шуман. «Альбом для юнацтва». \\
\hline
\end{tabular}

Наведемо приклади прийомів музичної терапії для вихователів ДН3: 1) Недирективна медитація для дітей старшого дошкільного віку. Мета заняття: заспокоєння дітей, зняття емоційної напруги, зменшення відчуття тривоги й невпевненості. Обладнання: музичний програвач, аудіозапис. Методика проведення: запрошуємо дітей зручно сісти на стільчики, звернути увагу на своє дихання, зосередитися на звуках музики, не відволікатись, «відправитись» до країни чарівних звуків, яскравих образів, настроїв і барв. Чарівливі звуки можуть перетворити нас на різних героїв, казкових персонажів. Пропонуємо прослухати музичний твір. Під час сприйняття музики вихователь веде бесіду-розповідь: «Діти, ми з вами можемо не лише слухати музику, а вдихати ії аромат, відчувати його на своєму язиці, відчувати шкірою. Мелодія, що звучить, веде нас, мов стежинка, якою ми 3 вами подорожуємо. Можемо перетворитись на диригентів i продиригувати музику, що чуємо. Подумайте, який настрій у мелодії? Яку назву ми б дали цьому музичному твору? Чому? Чи пробуджує мелодія якісь почуття у вас? Які бажання викликає ця музика? Які думки навіює нам музика? Якого героя вам нагадує музичний настрій?». Обговорення ідей та образів, що виникають під час музичного сприйняття, сприяє більш глибокому пізнанню членів групи й самих себе, один одного, і це сприяє зміцненню товариськості у групі, доброзичливості між її представниками.

2) Музично-психологічний масаж. Мета: тренування рухомості нервових процесів; уважно ставитись до свого тіла, контролювати м'язові та психологічні утиски, що супроводжують напружену діяльність. Обладнання: музичний програвач, аудіозапис. Методика проведення: учасникам групи пропонуємо прослухати (зосереджено) насичений негативними афектами музичний фрагмент до 1,5-2 хвилин звучання, намагаючись пригадати епізоди зі свого життя, що підходять під пропоновану музику. Згадати та пережити заново. Потім вихователь промовляє : «СТОП!» і вмикає плавну, спокійну 
музику. Завдання в умовах цієї ситуації - миттєво скинути, мов баласт, м'язову напругу, що виникає під час негативного переживання. Спектр емоцій може бути таким: від образи, злості, страху - до радості, заспокоєння, умиротворення. Рекомендується використовувати такі музичні фрагменти на вибір: а) С. Прокоф’єв. «Мана» («Наваждение»); б) Ф. Шопен. Ноктюрн. Мі-бемоль мажор; а) Р. Щедрин. «Скачки» 3 балету «Анна Каренина»; б) 3. Фибих. Поема.; а) Л.Бетховен. Соната № 14 «Місячна» (Фінал); б) Й. Штраус. Вальс «Голубий Дунай».

Під час прослуховування першого фрагменту: «Чітко уявіть собі неприємну ситуацію. Відчувайте тривогу, неспокій, дозвольте собі відчути хвилювання. Напружте м'язи тіла. Негативні емоції повністю оволоділи вами». Після команди «СТОП!» вихователь вмикає приємну, спокійну музику. «Миттєво позбулися свого внутрішнього навантаження, повністю залишили зону негативних емоцій. Розслабили всі м'язи (ручки, ніжки, шії, обличчя, спину). Уявили себе серед природи. Вдихаємо аромат троянд, прогулюємось залитою сонцем стежиною. Ми спокійно дихаємо, нам приємно, тепло. Ми повністю забули неприємні спогади. На згадку приходять любі серцю образи, добрі друзі, теплі обійми».

Пропонований прийом тренує рухомість нервових процесів, а також вчить уважно ставитись до свого тіла, розуміти його вияви, контролювати м'язові та психологічні утиски. Відпрацювання афекту на невербальному рівні закріплюється потім і словесним обговоренням пережитих емоцій, у такий спосіб досягається єдність почуттів і думок, що вичерпує негативні емоції.

Успішність музичної діяльності вихователя щодо музично-терапевтичного впливу на дошкільників визначається довершеним знанням, розумінням, осмисленням музичних творів, що ним використовуються, а також чітким усвідомлення цілей музичнотерапевтичного впливу; дотриманням принципів формування музичного репертуару (послідовність творів) і відповідністю психологічному клімату між дітьми; довірливою, комфортною атмосферою між дітьми та вихователем; наміром креативно розвивати дошкільників засобами музичного мистецтва. Адже загальновідомою $\epsilon$ думка В. Сухомлинського про те, що у структурі людських художніх смаків музика посідає перше місце, випереджаючи інші види мистецтва. Вона є компонентом багатьох інших синтетичних видів мистецтв, формує середовище, створює унікальні умови для людського суспільства сприймати прекрасне в житті й мистецтві, допомагає людині стати чуйною, впливає на всі складники її психіки - уяву, почуття, мислення, волю, здібності. Отже, упровадження музикотерапії в практику ДНЗ уможливлює тотальний уплив на особистість дитини на трьох рівнях: фізіологічному, психічному, сакральному; сприяє розвитку комунікативних актів, творчої уяви, фантазії; розширенню емоційної сфери; релаксації психологічного тонусу; розвитку почуття товариськості.

\section{Література}

1. http://propolka.pp.ua/issledovanie_vlijanija_muziki.html 2. Білодід Ю. М. Духовність: сутність, структура, функції: [монографія] | Ю.М. Білодід. - Житомир: Редакційно-видавничий відділ ІПСТ, 2003. - 192 с. 3. Музично-енциклопедичний словник. - К.,1991. - С. 359. 4. Петрушин В. И. Музыкальная психотерапия: теория и практика: [учеб. пособие для студ.высш.учеб.заведений]. М. : Гуманит. изд. центр ВЛАДОС, 2011. - 176 с. 5. Побережная Г. И. Музыка в детской душе / Г. И. Побережная. - К., 2007. - С. 24. 6. Саранин В. П. Музыка как смыслообразующая константа жизнедеятельности человека: автореф. дис. на соискание ученой степени канд. фил. наук : спец. : 24.00.01 «Теория и история культуры» / Владимир Петрович Саранин. - Тамбов, 2003. - 19 с. 7. Холопова В. Понятие «Музика» / В. Холопова // Музыкальная академия. - № 4. - 2003. - С. 1 18. 8. Энциклопедия символов, знаков, эмблем. - М., 2001.- 334 с. 